\title{
Stability of cashew apple juice in powder dehydrated in spouted bed
}

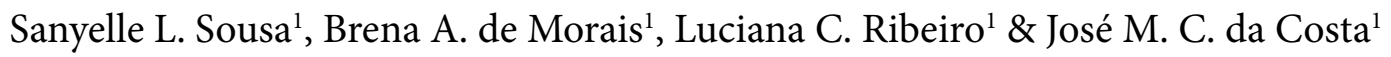 \\ ${ }^{1}$ Universidade Federal do Ceará/Departamento de Tecnologia de Alimentos. Fortaleza, CE. E-mail: sanyellelima@yahoo.com.br (Corresponding author); \\ brena-am@hotmail.com; ribeiro.lucianac@gmail.com; correiacostaufc@gmail.com
}

\section{Key words:}

Anacardium occidentale L. fruit powder

dehydration

\begin{abstract}
A B S T R A C T
This study evaluated the stability of cashew apple juice in powder, dehydrated in spouted bed and stored in two vacuum-sealed packages (laminated and plastic) for a period of 60 days. The parameters evaluated in this study were ascorbic acid, carotenoids, moisture, water activity, hygroscopicity, degree of caking, solubility and rehydration. Decreases in the contents of ascorbic acid and carotenoids were observed after 60 days. Moisture content remained practically unchanged during storage, and water activity showed a rising trend in the plastic package. In both packages, the powder showed low hygroscopicity and high caking formation. The solubility in both packages was higher than $90 \%$ and the time of rehydration of cashew apple juice in powder in the plastic package increased during storage. Cashew apple juice in powder stored in laminated package preserved better its physical and physico-chemical properties.
\end{abstract}

\section{Palavras-chave:}

Anacardium occidentale L. fruta em pó

desidratação

\section{Estabilidade do suco de caju em pó desidratado em leito de jorro}

\section{R E S U M O}

Propôs-se, neste trabalho, avaliar a estabilidade do suco de caju em pó desidratado em leito de jorro e acondicionado em duas embalagens (laminada e plástica) seladas a vácuo pelo período de 60 dias. Os parâmetros avaliados foram: o ácido ascórbico, carotenoides, umidade, atividade de água, higroscopicidade, grau de caking, solubilidade e reidratação. Observaram-se, após os 60 dias, reduções nos teores de ácido ascórbico e carotenoides. A umidade praticamente não variou ao longo do armazenamento; já a atividade de água apresentou tendência de elevação na embalagem plástica. Em ambas as embalagens o pó apresentou baixa higroscopicidade porém com elevada formação de caking. As solubilidades nas duas embalagens foram superiores a $90 \%$ e o tempo necessário para reidratar o suco de caju em pó da embalagem plástica aumentou ao longo do armazenamento. O suco de caju em pó acondicionado na embalagem laminada a vácuo conservou melhor suas propriedades físicas e físico-químicas. 


\section{INTRODUCTION}

Dehydration is one of the most commonly used operations in the food industry, because it involves the transfer of energy and mass under controlled conditions of temperature, relative humidity, pressure and air speed, in order to remove the water present in the food (Fellows, 2006). The spouted bed technique is a dehydration process developed in 1954 by two Canadian researchers, who initially created it for the drying of wheat. In the following years, it was object of studies conducted with different materials, expanding the knowledge on this process and its application (Epstein \& Grace, 2011).

Drying of tropical fruits using spouted bed has been widely studied because of the quality of the powder products that have been obtained (Medeiros et al., 2002). Fruit juices stand out for their various advantages, such as low cost, practicality, easy handling and high yield. In this context, the use of regional fruits such as cashew (Anacardium occidentale L.), which has great potential, for its characteristic taste and its nutritional composition, containing phenolic compounds, flavonoids, tannins, sugars and ascorbic acid, guarantees good acceptance by the consumers (Freire et al., 2013).

Dehydrated products have longer lifetime, due to the removal of water, inhibition of growth of microorganisms and activity of some enzymes, and certain chemical and biochemical reactions. Although water activities below 0.6 are already sufficient to avoid microbiological alterations, chemical and enzymatic modifications may continue to occur at water activity levels below the previously mentioned one (Azeredo et al., 2012).

Thus, packaging plays an important role in the maintenance of quality, because it protects the product from external environmental factors, such as temperature, relative air humidity, light and physical damages. Therefore, the selection of the best package is relevant to minimizing undesirable alterations and extending the lifetime of the product. Based on the above, this study aimed to evaluate the stability of cashew apple juice in powder, dehydrated in spouted bed, stored in two types of vacuum-sealed packaging for the period of 60 days.

\section{Material AND Methods}

The raw material used was cashew apple juice in powder, containing $88 \%$ of whole cashew apple juice and $12 \%$ of maltodextrin $(\mathrm{DE}<20)$ dehydrated in a spouted bed dryer (Model FBD 5.0, Labmaq do Brasil Ltda) under the following drying conditions: drying air temperature of $80^{\circ} \mathrm{C}$, drying air flow rate of $1.5 \mathrm{~m}^{3} \mathrm{~min}^{-1}$, feeding speed of $4.5 \mathrm{~mL} \mathrm{~min}{ }^{-1}$, compressed air flow rate of $3.0 \mathrm{~L} \mathrm{~min}^{-1}$ and mass of the inert material of $400 \mathrm{~g}$.

The study on the stability of cashew apple juice in powder required 22 dryings in the spouted bed, in order to obtain sufficient amount for the experiment. Then, all the powder was homogenized and distributed in equal amounts (portions of approximately $25 \mathrm{~g}$ ) in laminated and plastic packages. After that, the packages were vacuum-sealed and stored under ambient temperature.

The following packages were used: transparent plastic package, formed by the combination of PA (Polyamide) +
PE (Polyethylene), and golden-colored laminated package, formed by the combination of Aluminum, PET (Polyethylene Terephthalate) and polyamide.

The analyses performed in the cashew apple juice in powder were: ascorbic acid, carotenoids, moisture, water activity, hygroscopicity, degree of caking, solubility and rehydration. Ascorbic acid was determined through the titration method, using 2,6-dichlorophenolindophenol (DCPIP), according to the methodology proposed by Strohecker \& Henning (1967). Total carotenoids were determined through the methodology of Lichtenthaler (1987), which consists in the extraction of carotenoids using acetone (80:20) from approximately $0.5 \mathrm{~g}$ of the juice in powder, followed by homogenization and subsequent reading in a spectrophotometer.

Moisture content was determined using a Marte ID 50 moisture analyzer and water activity was determined in an AquaLab 4 TEV water activity meter at the temperature of 25 ${ }^{\circ} \mathrm{C}$, calibrated with distilled water, according to the indication of the manufacturer.

Hygroscopicity was determined according to the methodology of Goula \& Adamapoulos (2010); approximately $1 \mathrm{~g}$ of sample was weighed on a Petri dish and maintained in hermetic container with saturated solution of $\mathrm{NaCl}$ (relative humidity of 75\%). Hygroscopicity was expressed as g of

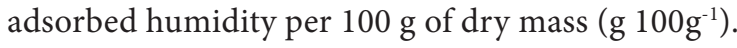

The samples from hygroscopicity analysis were used for the determination of degree of caking and subjected to drying in a forced-air oven for $1 \mathrm{~h}$ at $102{ }^{\circ} \mathrm{C}$. After cooling, the sample was transferred to a granulometric sieve $(500-\mu \mathrm{m}$ mesh) and maintained under agitation for $5 \mathrm{~min}$. The powder retained by the sieve was weighed and the degree of caking was determined based on the methodology of Jaya \& Das (2004). For comparison purposes, the standards of hygroscopicity and degree of caking established by GNL (2003) were used.

Solubility analysis was performed according to the methodology of Cano-Chauca et al. (2005) and the time of powder rehydration according to Goula \& Adamopoulos (2010). The analysis were performed in triplicate and the results of the analytical determinations were evaluated through analysis of variance (ANOVA) and Tukey test at 0.05 probability level, using the program Statistica, version 7.0 (Statsoft, 2007).

\section{Results AND Discussion}

Mean values of ascorbic acid and carotenoids of cashew apple juice in powder are shown in Table 1. For ascorbic acid, there was a difference between packages only in the periods of 0 and 45 days. According to the obtained results, there was no significant loss in the laminated package in the first 15 days, but it differed from the other periods. At the end of 60 days of storage, the cashew apple juice in powder stored in laminated package showed the lowest content of ascorbic acid, but differed significantly from the powder stored in plastic package, so that the preservation of this constituent was not influenced by the package in the final period.

In the plastic package, the content of ascorbic acid did not vary statistically until 30 days; from 45 days on, there 
Table 1. Physico-chemical parameters of ascorbic acid and carotenoids of cashew apple juice in powder along 60 days of storage in different vacuum-sealed packages ${ }^{*}$

\begin{tabular}{|c|c|c|c|c|}
\hline \multirow{2}{*}{$\begin{array}{l}\text { Time } \\
\text { (days) }\end{array}$} & \multicolumn{2}{|c|}{ Ascorbic acid (mg $\left.100 \mathrm{~g}^{-1}\right)$ d. b. } & \multicolumn{2}{|c|}{ Carotenoids $\left(\mathbf{g} 100 \mathrm{~g}^{-1}\right) \mathrm{d} . \mathrm{b}}$. \\
\hline & LP & PP & LP & PP \\
\hline 0 & $610.88 \mathrm{cB} \pm 22.62$ & $678.65 a b A \pm 17.22$ & $0.16 \mathrm{aA} \pm 0.02$ & $0.11 a b A \pm 0.05$ \\
\hline 15 & $638.62 \mathrm{bcB} \pm 21.41$ & $697.56 a b A \pm 27.45$ & $0.11 \mathrm{abAB} \pm 0.07$ & $0.11 a b A \pm 0.04$ \\
\hline 30 & $726.53 \mathrm{a} A \pm 24.48$ & $704.50 \mathrm{abA} \pm 11.55$ & $0.11 \mathrm{abAB} \pm 0.01$ & n. d. \\
\hline 45 & $698.75 a b A \pm 23.44$ & $577.46 \mathrm{cdB} \pm 23.65$ & $0.16 \mathrm{aA} \pm 0.07$ & n. d. \\
\hline 60 & $537.15 \mathrm{dC} \pm 16.31$ & $525.56 \mathrm{~dB} \pm 34.66$ & $0.01 \mathrm{bB} \pm 0.06$ & n. d. \\
\hline
\end{tabular}

${ }^{*}$ LP - Laminated package; PP - Plastic package; (n. d.) not determined; Means followed by the same letter do not differ ( $\left.p \geq 0.05\right)$ by Tukey test (for the same analysis), uppercase letters in the column (for the same package) and lowercase letters in the row (between packages)

was a sharp reduction of ascorbic acid in this package, which continued until the end of storage and was also observed by Moreira et al. (2011) in 'cupuaçu' (Theobroma grandiflorum) pulp powder and by Galdino et al. (2003) in 'umbu' (Spondias tuberosa) pulp powder. These results are expected, considering the barrier properties of this package and its susceptibility to humidity, light and other factors that contribute to the reduction of ascorbic acid.

As to the content of carotenoids, there was no difference between the types of vacuum-sealed packages in the periods of 0 and 15 days in the cashew apple juice in powder. From this period on, no carotenoids were detected in the cashew apple juice in powder stored in vacuum-sealed plastic package. Such instability may be associated with the exposure of the product to the light, due to the nature of the package. In this case, the transparency favored this process of degradation of carotenoids, as reported by Freitas et al. (2006) in 'acerola' (Malphigia emarginata DC.) tropical juice.

In the laminated package, the content of carotenoids did not vary statistically until the period of 45 days, but a significant reduction was observed after 60 days of storage. The high contents of sugar present in the powder may have compromised the process of extraction of carotenoids, for interacting or competing with the other components of the system, affecting the readings of the spectrophotometer, as observed by Alves et al. (2008) in the 'pequi' (Caryocar brasiliense Camb.) pulp in powder.

The values of moisture and water activity of the cashew apple juice in powder are shown in Table 2. For comparison purposes, the moisture of cashew apple juice in powder obtained in spouted bed showed values higher than those observed by Araújo et al. (2015) in acerola (Malphigia emarginata DC.) juice dehydrated in spouted bed (1.95\%) and by Rocha et al. (2014) in spray-dried cashew juice in powder (1.04\%); however, it was lower than the moisture of lyophilized mango (Mangifera indica, L.) pulp powder (3.14\%) obtained by Moreira et al. (2013).

According to the obtained results, except for the period of 15 days, there was no difference between the moisture values of both types of package, showing that cashew apple juice in powder stored for 60 days has no variation in this parameter, regardless of the package used. Along 60 days of storage, the moisture content did not vary in the laminated package; for the plastic package, only the period of 15 days differed statistically from the others.

Moisture maintenance in vacuum-sealed packages was also observed by Ramos et al. (2008) in pineapples dehydrated and stored in vacuum-sealed polyvinylidene chloride package, in which moisture remained stable along 75 days of storage. However, in mango pulp and cashew apple juice in powder, stored in laminated and plastic packages without vacuum, Rocha (2013) observed, in both packages, the gradual increase in moisture during the 180 days of storage; therefore, the combination of packages and the applied vacuum were the factors that contributed to the maintenance of this parameter in cashew apple juice in powder obtained in spouted bed.

The moisture data may contribute to the hypothesis that the vacuum storage in the studied packages favors the reduction of gas exchanges with external environment. However, water activity values are the ones that reflect the actual behavior of cashew apple juice in powder in both packages and explain the shorter lifetime of the product stored in plastic package. According to Azeredo et al. (2012), moisture content can not be considered as the only indicator of chemical reactivity in the food, and water activity reflects better the concentration of water available for chemical reactions.

In the comparison of water activity in cashew apple juice in powder stored in both vacuum-sealed packages, both packages differed $(\mathrm{p}<0.05)$ from 15 days of storage on and maintain such difference until the 60 days. For the plastic package, there was a consistent increase in water activity along the storage, which remained the same in the periods of 30 and 45 days and was rapidly resumed in the period of 60 days. This increase was also observed by Todisco et al. (2013) in 'siriguela' (Spondias purpurea L.) pulp powder stored in plastic package without vacuum.

Table 2. Moisture and water activity of cashew apple juice in powder along 60 days of storage in different vacuumsealed packages*

\begin{tabular}{|c|c|c|c|c|}
\hline \multirow{2}{*}{$\begin{array}{c}\text { Time } \\
\text { (days) }\end{array}$} & \multicolumn{2}{|c|}{ Moisture (\%) } & \multicolumn{2}{|c|}{ Water activity } \\
\hline & LP & PP & LP & PP \\
\hline 0 & $2.39 \mathrm{aA} \pm 0.13$ & $2.39 \mathrm{aB} \pm 0.18$ & $0.18 \mathrm{eB} \pm 0.00$ & $0.18 \mathrm{eD} \pm 0.00$ \\
\hline 15 & $2.58 \mathrm{aA} \pm 0.31$ & $2.89 \mathrm{bA} \pm 0.20$ & $0.18 \mathrm{eB} \pm 0.00$ & $0.22 b C \pm 0.00$ \\
\hline 30 & $2.47 \mathrm{aA} \pm 0.16$ & $2.37 \mathrm{aB} \pm 0.12$ & $0.19 \mathrm{dA} \pm 0.00$ & $0.25 \mathrm{cB} \pm 0.00$ \\
\hline 45 & $2.29 \mathrm{aA} \pm 0.13$ & $2.01 \mathrm{aB} \pm 0.12$ & $0.19 \mathrm{dA} \pm 0.00$ & $0.25 c B \pm 0.00$ \\
\hline 60 & $2.22 \mathrm{aA} \pm 0.07$ & $2.20 \mathrm{aB} \pm 0.13$ & $0.19 \mathrm{dA} \pm 0.00$ & $0.30 \mathrm{aA} \pm 0.00$ \\
\hline
\end{tabular}

* LP - Laminated package; PP - Plastic package; Means followed by the same letter do not differ ( $\mathrm{p} \geq 0.05$ ) by Tukey test (for the same analysis), uppercase letters in the column (for the same package) and lowercase letters in the row (between packages) 
Water activity in cashew apple juice in powder stored in vacuum-sealed laminated package remained constant in the first 15 days; from 30 days on, there was an increase, which remained until the end of the storage of 60 days. In general, the laminated package showed superiority in the maintenance of water activity, based on absolute values, due to the its better barrier properties.

The results of hygroscopicity and degree of caking of cashew apple juice in powder are shown in Table 3. According to the standards established by GNL (2003), cashew apple juice in powder stored in both vacuum-sealed packages presented itself as a non-hygroscopic powder and contradicts the tendency of fruit powders to absorb water, forming hard agglomerates (caking). Such behavior was also observed by Oliveira et al. (2013) in lyophilized powder of grugru palm (Acrocomia aculeata), which showed low values of hygroscopicity, due to the larger size of powder particles; as a consequence, a smaller surface of contact is exposed for the binding with water.

The hygroscopicity of cashew apple juice in powder was different between vacuum-sealed packages only in the periods of 30 and 60 days; the powder stored in laminated package showed stable hygroscopicity along the storage of 60 days. In the plastic package, there was a tendency of reduction along the 60 days of evaluation and the hygroscopicity at 15 days was different from the values at 30 and 45 days, while the period of 60 days differed from the others.

These results are consistent with the previously presented values of water activity, in which the laminated package showed the lowest values; as a result, hygroscopicity remained constant. In the plastic package, however, the powder adsorbed water because of the inefficient barrier, and the water easily bound with the low-molecular weight molecules (fructose, glucose and sucrose) present in the juice in powder. With this greater incorporation of water from the environment by the product, the powder showed lower values of hygroscopicity along the storage, due to the lower availability for new bonds with water molecules from the outside.
Based on the values of degree of caking of cashew apple juice in powder in both packages (Table 3), the powders can be classified as with high caking formation, according to the standards of GNL (2003). There was great variation in the values of both packages, which can be explained by the difficulties of the methodology, especially during the transfer of the powder to the granulometric sieve, due to the high degree of caramelization of the juice in powder after the oven.

The high values of degree of caking obtained in cashew apple juice in powder are expected, because it has lowmolecular weight sugars in its composition, which contribute to the reduction of vitreous transition temperature and favor the agglomeration processes of the powders (Goula \& Adamopoulos, 2010).

There was difference in the degree of caking between the packages only in the period of 15 days, individually, in the cashew apple juice in powder stored in plastic package. The degree of caking of the period of 0 day varied in relation to 15 days. For the cashew apple juice in powder stored in laminated package, the degrees of caking of the periods of 0,15 and 30 days were different and then remained stable until the end of the storage.

Solubility values are shown in Table 4 . In general, cashew apple juice in powder showed difference between the packages only in the period of 30 days. Individually, the period of 0 day for the laminated package differed from the periods of 15 and 60 days, while for the plastic package there was only difference between the periods of 15 and 30 days.

Solubility is related to the interaction between chemical substances and is a quantitative term to express the solubilization of a product in the solvent, which is the substance that dissolves it (Martins et al., 2013). Considering that, in the composition of the cashew apple juice in powder, there are sugars easily soluble in water, these high values of solubility are already expected, regardless of the package used.

According to Table 4, there was difference between the packages in the time of rehydration of the powders from

Table 3. Hygroscopicity and degree of caking of cashew apple juice in powder along 60 days of storage in different vacuum-sealed packages*

\begin{tabular}{|c|c|c|c|c|}
\hline \multirow{2}{*}{$\begin{array}{l}\text { Time } \\
\text { (days) }\end{array}$} & \multicolumn{2}{|c|}{ Hygroscopicity $\left({\left.\mathrm{g} 100 \mathrm{~g}^{-1}\right)}\right.$} & \multicolumn{2}{|c|}{ Degree of caking (\%) } \\
\hline & LP & PP & LP & PP \\
\hline 0 & $9.41 \mathrm{abA} \pm 0.26$ & $7.70 a b c A B \pm 0.29$ & $74.69 \mathrm{abcB} \pm 8.62$ & $86.87 \mathrm{aA} \pm 3.60$ \\
\hline 15 & $8.54 a b c A \pm 0.38$ & $8.28 a b c A \pm 0.23$ & $88.92 \mathrm{aA} \pm 2.54$ & $63.40 \mathrm{bcB} \pm 7.31$ \\
\hline 30 & $9.51 \mathrm{aA} \pm 1.56$ & $7.60 \mathrm{bcB} \pm 0.21$ & $59.12 c C \pm 2.65$ & $74.51 \mathrm{abcAB} \pm 9.07$ \\
\hline 45 & $7.96 a b c A \pm 0.93$ & $7.39 \mathrm{cB} \pm 0.27$ & $78.23 \mathrm{abAB} \pm 2.03$ & $78.25 a b A B \pm 5.78$ \\
\hline 60 & $8.53 a b c A \pm 0.40$ & $4.70 \mathrm{dC} \pm 0.13$ & $79.67 \mathrm{aAB} \pm 3.42$ & $79.20 \mathrm{aAB} \pm 2.48$ \\
\hline
\end{tabular}

* LP - Laminated package; PP - Plastic package; Means followed by the same letter do not differ ( $\mathrm{p} \geq 0.05$ ) by Tukey test (for the same analysis), uppercase letters in the column (for the same package) and lowercase letters in the row (between packages)

Table 4. Solubility and rehydration of cashew apple juice in powder along 60 days of storage in different vacuumsealed packages*

\begin{tabular}{|c|c|c|c|c|}
\hline \multirow{2}{*}{$\begin{array}{l}\text { Time } \\
\text { (days) }\end{array}$} & \multicolumn{2}{|c|}{ Solubility (\%) } & \multicolumn{2}{|c|}{ Rehydration (seconds) } \\
\hline & LP & PP & LP & PP \\
\hline 0 & $95.05 \mathrm{aA} \pm 0.24$ & $93.57 \mathrm{abAB} \pm 0.50$ & $45.0 \mathrm{dA} \pm 0.00$ & $45.0 \mathrm{dC} \pm 0.00$ \\
\hline 15 & $93.48 \mathrm{abB} \pm 0.32$ & $95.05 \mathrm{aA} \pm 0.23$ & $45.0 \mathrm{dA} \pm 0.00$ & $60.0 \mathrm{dBC} \pm 0.00$ \\
\hline 30 & $95.05 \mathrm{aA} \pm 0.24$ & $91.61 \mathrm{bB} \pm 1.68$ & $45.0 \mathrm{dA} \pm 0.00$ & $82.5 c B \pm 10.61$ \\
\hline 45 & $94.21 \mathrm{abAB} \pm 0.94$ & $93.15 \mathrm{bAB} \pm 0.85$ & $45.0 \mathrm{dA} \pm 0.00$ & $150.0 \mathrm{bA} \pm 0.00$ \\
\hline 60 & $93.73 \mathrm{abB} \pm 0.29$ & $93.34 \mathrm{abAB} \pm 0.42$ & $45.0 \mathrm{dA} \pm 0.00$ & $172.5 \mathrm{aA} \pm 10.61$ \\
\hline
\end{tabular}

LP - Laminated package; PP - Plastic package; Means followed by the same letter do not differ ( $\mathrm{z} \geq 0.05$ ) by Tukey test (for the same analysis), uppercase letters in the column (for the same package) and lowercase letters in the row (between packages) 
30 days of storage on. In the laminated package, the time of rehydration remained constant during the entire period of evaluation; however, in the plastic package, due to the greater adsorption of water by the powder, more granules (caking) were formed, which required a longer time to dissolve under agitation.

\section{Conclusions}

1. Cashew apple juice in powder stored in vacuum-sealed laminated package showed higher stability in the storage of 60 days, for better preserving physical and physico-chemical properties, in comparison to the vacuum-sealed plastic package.

2. Cashew apple juice in powder stored in vacuum-sealed plastic package adsorbed water during the entire storage, due to the lower capacity of protection of the package; thus, it became a hard and agglomerated powder, losing its functionality and quality.

\section{Literature Cited}

Alves, C. C. O.; Resende, J. V.; Cruvinel, R. S. R.; Prado, M. E. T. Estabilidade da microestrutura e do teor de carotenóides de pós obtidos da polpa de pequi (Caryocar brasiliense Camb.) liofilizada. Food Science and Technology, v.28, p.830-839, 2008. http://dx.doi. org/10.1590/S0101-20612008000400011

Araújo, A. D. A.; Coelho, R. M. D.; Fontes, C. P. M. L.; Silva, A. R. A.; Costa, J. M. C.; Rodrigues, S. Production and spouted bed drying of acerola juice containing oligosaccharides. Food and Bioproducts Processing, v.94, p.565-571, 2015. http://dx.doi. org/10.1016/j.fbp.2014.08.005

Azeredo, H. M. C.; Brito, E. S.; Garruti, D. S. Alterações químicas em alimentos durante a estocagem. In: Azeredo. H. M. C. (ed.) Fundamentos da estabilidade de alimentos. Brasília: Embrapa. 2012. Cap.2, p.15-38.

Cano-Chauca, M.; Stringheta, P. C.; Ramos, A. M.; Cal-Vidal, J. Effect the carriers on the microstructure of mango powder spray drying and its functional characterization. Innovative Food Science \& Emerging Technologies, v.6, p.420-428, 2005. http://dx.doi. org/10.1016/j.ifset.2005.05.003

Epstein, N.; Grace, J. R. Introduction. In: Epstein, N.; Grace, J. R. (ed.) Spouted and spout-fluid beds: Fundamentals and applications. New York: Cambridge University Press. 2011. Cap.1, p.1-14.

Fellows, P. J. Tecnologia do processamento de alimentos - Princípios e prática. Porto Alegre: Artemed, 2006. 602p.

Freire, J. M.; Abreu, C. M. P.; Rocha, D. A.; Corrêa, A. D.; Marques, N. R. Quantificação de compostos fenólicos e ácido ascórbico em frutos e polpas congeladas de acerola, caju, goiaba e morango. Ciência Rural, v.43, p.2291-2296, 2013. http://dx.doi.org/10.1590/ S0103-84782013005000132

Freitas, C. A. S.; Maia, G. M.; Costa, J. M. C.; Figueiredo, R. W.; Sousa, P. H. M.; Fernandes, A. G. Estabilidade dos carotenoides, antocianinas e vitamina $\mathrm{C}$ presente $\mathrm{n}$ suco tropical de acerola (Malpigh emarint DC.) Adoçado e envasado pelo processo hotfill e asséptico. Ciência e Agrotecnologia, v.30, p.942-949, 2006. http://dx.doi.org/10.1590/S1413-70542006000500018
Galdino, P. O.; Queiroz, A. J. de M.; Figueirêdo, R. M. F. de; Silva, R. N. G. Avaliação da estabilidade da polpa de umbu em pó. Revista Brasileira de Produtos Agroindustriais, v.5, p.73-80, 2003. http:// dx.doi.org/10.15871/1517-8595/rbpa.v5n1p73-80

GNL - Gea Niro Laboratory. Analytical methods dry milk products by GEA Niro - Analytical methods, Methods 14 and 15 a. Soeborg: GEA Niro, 2003.

Goula, A. M.; Adamopoulos, K. G. A new technique for spray drying orange juice concentrate. Innovative Food Science and Emerging Technologies, v.11, p.342-351, 2010. http://dx.doi.org/10.1016/j. ifset.2009.12.001

Jaya, S.; Das, H. Effect of maltodextrin, glycerol monostearate and tricalcium phosphate on vaccum dried mango powders properties. Journal of Food Engineering, v.63, p.125-134, 2004. http://dx.doi. org/10.1016/S0260-8774(03)00135-3

Lichtenthaler, H. K. Chlorophylls and carotenoids: Pigments of photosynthetic biomembranes. Methods in enzymology, v.148, p.346-382, 1987. http://dx.doi.org/10.1016/0076-6879(87)48036-1

Martins, C. R.; Lopes, W. A.; Andrade, J. B. Solubilidade das substâncias orgânicas. Química Nova, v.36, p.1248-1255, 2013. http://dx.doi.org/10.1590/S0100-40422013000800026

Medeiros, M. F. D.; Rocha, S. C. S.; Alsina, O. L. S. Jerônimo, C. E. M.; Medeiros, U. K. L.; Mata, L. M. L. Drying of pulps of tropical fruits in spouted bed: Effect of composition on dryer performance. Drying Technology, v.20, p.855-881. 2002. http:// dx.doi.org/10.1081/DRT-120003767

Moreira, J. S. A.; Souza, M. L.; Araújo Neto, S. E.; Silva, R. F. Estudo da estabilidade microbiologica e fisico-quimica de polpa de cupuaçu desidratada em estufa. Revista Caatinga, v.24, p.26-32, 2011.

Moreira, T. B.; Rocha, E. M. F. F.; Afonso, M. R. A.; Costa, J. M. C. Comportamento das isotermas de adsorção do pó da polpa de manga liofilizada. Revista Brasileira de Engenharia Agrícola e Ambiental, v.17, p.1093-1098, 2013. http://dx.doi.org/10.1590/ S1415-43662013001000011

Oliveira, D. M.; Clemente, E.; Afonso, M. R. A.; Costa, J. M. C. Hygroscopic behavior of lyophilized powder of grugru palm (Acrocomia aculeata). American Journal of Analytical Chemistry, v.4, p.1-7, 2013. http://dx.doi.org/10.4236/ajac.2013.410A3001

Ramos, A. M.; Quintero, A. C. F.; Faraoni, A. S.; Soares, N. F. F.; Pereira, J. A. M; Efeito do tipo de embalagem e do tempo de armazenamento nas qualidades físico-química e microbiológica de abacaxi desidratado. Revista Alimentos e Nutrição, v.19, p.259-269, 2008.

Rocha, E. M. F. F. Desidratação de polpa de manga e suco de caju integral por atomização e caracterização dos produtos obtidos. 146 p. Fortaleza: UFC, 2013. Tese Doutorado

Rocha, E. M. F. F.; Sousa, S. L.; Costa, J. P.; Rodrigues, S.; Afonso, M. R.A.; Costa, J. M. C. C. Obtenção do suco de caju atomizado através do controle das condições de secagem. Revista brasileira de Engenharia Agrícola e Ambiental, v.18, p.646-651, 2014. http:// dx.doi.org/10.1590/S1415-43662014000600012

Statsoft. Statistica for Window - Computer programa manual. Versão 7.0 Tulsa: Statsoft Inc. 2007.

Strohecker, R.; Henning, H. M. Analisis de vitaminas: Métodos comprobados. Madrid: Paz Montalvo, 1967. 428p.

Todisco, K. M.; Costa, J. M. C.; Rodrigues, S.; Clemente, E. Microencapsulation of Red Mombi (Spondias purpurea L.) pulp using spray-drying. International Journal of Sciences, v.2, p.111, 2013. 